\title{
NUTRITIONAL PROPERTIES OF SAKADA PRODUCED FROM BLENDS OF CASSAVA AND AFRICAN YAM BEAN FLOURS
}

- Research paper -

\author{
Oluwafemi AJAYI*, Gibson ARUEYA**, Olajide ADEDEJI ${ }^{1 * * *}$, Ajose AKINLABI** $^{* *}$ \\ *Fisheries and Aquaculture Division, Food and Agriculture Organization of the United Nations, \\ Rome, Italy. \\ ** Department of Food Technology, University of Ibadan, Ibadan, Nigeria. \\ **** Department of Food Science and Technology, Federal University Wukari, Wukari, Nigeria.
}

\begin{abstract}
This study investigated the effect of African yam bean flour (AYF) inclusion on the quality of sakada. Fermented cassava mash (FCM) and AYF were blended at ratios (\% w/w) 100:0 (control), 90:10, 80:20, 70:30, and 60:40. Sakada was produced using the blends, and its nutritional and sensory properties were determined. Protein, fat, crude fibre, P, Ca, phytate, and oxalate contents of sakada increased ( $\mathrm{p}<0.05)$ with increasing AYF level, while moisture, carbohydrate, and cyanide decreased. The incorporation of $20 \%$ AYF in sakada resulted in a significant amount (> 4.0 $\mathrm{g} / 100 \mathrm{~g}$ protein) of arginine, leucine, isoleucine, and phenylalanine. Sensory properties of sakada that contained $\leq 20 \%$ AYF compared favourably with sakada produced using 100\% FCM. This study showed that the nutritional quality of sakada improved following AYF incorporation.
\end{abstract}

Keywords: African yam bean, cassava mash, enrichment, sakada, snack

\section{INTRODUCTION}

Cassava (Manihot esculentus Crantz) is a staple food and an excellent energy source in sub-Saharan Africa (Laswai et al., 2017). The bulk of the global cassava tonnage, roughly 291 million tons, is produced in West Africa and South America (FAO, 2020). With an annual production of 59 million tons, Nigeria accounts for approximately $20 \%$ of the global production (IITA, 2020). Carbohydrate is the predominant nutrient in cassava. Besides, other nutrients such as protein, carotene, calcium, and phosphorus are present in considerable quantity (Aristizabal et al., 2017). Cassava contributes significantly to food security in third world countries (Chadare et al., 2019).

In West Africa, cassava is subjected to operations, such as drying, fermentation, and cooking, to obtain different food products (Laya et al., 2018). Important cassava products in this region are gari, cassava flour, lafun, and fufu (Ajani et al., 2016). These products form part of the main diets of the people, especially those in rural communities (IITA, 2020). In recent times, the use of cassava for snacks, bread, and biscuit production, is increasing. This is

Received: 09.07.2020.

Accepted in revised form: 25.09.2020 due to the high cost of wheat as well as healthrelated issues associated with its consumption (Ocheme et al., 2018). Furthermore, there is an increase in the rate of urbanization, which has resulted in changes in feeding and dietary patterns (Maziya-Dixon et al., 2017). Several studies have shown the potential of cassava as an ingredient for the production of snacks and bakery products (Eduardo et al., 2013; Maziya-Dixon et al., 2017; Wordu and Akusu, 2016; Okoye and Ezeugwu, 2019). Cassava-based snacks such as sakada, ajogun, and gurudi are currently being marketed in rural markets in the Southern part of Nigeria (Obadina et al., 2013; Wordu and Akusu, 2016).

Sakada is a cassava-based snack that is highly relished by school-age children in the Southwestern part of Nigeria. The traditional production involves peeling and grating of cassava roots to produce a mash. The mash is subjected to simultaneous dewatering and solid-state fermentation for 4-5 days. The fermented mash is formed to a desired shape and size and roasted using a charcoal stove. Like many cassava-based foods of sub-Saharan Africa, sakada is deficient in essential nutrients such as proteins, amino acids, and minerals. Therefore, the continuous consumption of sakada may result in protein-energy malnutrition.

${ }^{1}$ Corresponding author. E-Mail address: adedeji@fuwukari.edu.ng 
Consequently, efforts aimed at improving the nutrient density of sakada is highly imperative. In the past few decades, the incorporation of vegetable proteins into many staple foods of African origin, to complement their nutrients, is increasing. Many studies have shown an improvement in the nutrient density of cassava-based products after their fortification or enrichment with vegetable proteins such as soybean, groundnut, cowpea, and African yam bean (Jisha et al., 2010; Wordu and Akusu, 2016; Maziya-Dixon et al., 2017; Akinwale et al., 2017).

African yam bean (Sphenostylis stenocarpa) is a leguminous crop, which is found in many parts of the Tropics (Olawuni et al., 2014). It is rich in macro- and micro nutrients. According to Ndidi et al. (2014), African yam bean contains $21.78 \%$ protein, $220.95 \mathrm{mg} / 100 \mathrm{~g} \mathrm{Ca}, 152 \mathrm{mg} / 100 \mathrm{~g} \mathrm{~K}, 33.28$ $\mathrm{mg} / 100 \mathrm{~g} \mathrm{P}$, and $3.75 \mathrm{mg} / 100 \mathrm{~g} \mathrm{Zn}$. According to Esan and Fasasi (2013), African yam bean is rich in lysine and threonine. Recent studies have shown an improvement in the nutritional compositions of some staple foods following the incorporation of African yam bean (Idowu, 2015; Banigo and KiinKabari, 2016). However, studies on the incorporation of African yam bean on the quality of cassava-based snacks are sparse. In this present study, the effect of African yam bean flour inclusion on the nutritional qualities of sakada was investigated.

\section{MATERIALS AND METHODS}

\section{Materials}

Cassava, Manihot esculentus Crantz (sweet variety), roots were procured from the International Institute for Tropical Agriculture while African yam bean was provided by the Institute of Agricultural Research and Training, both at Ibadan, Nigeria. Analytical grade reagents were used for experiment.

\section{Methods}

\section{Production of fermented cassava mash}

The method of Ajani et al. (2016) was used for the production of fermented cassava mash (FCM). Freshly harvested cassava roots were peeled, washed with clean water, and reduced into mash in a mechanical grater (Henan, Nigeria). The mash was poured into a sac and dewatered with the aid of locally fabricated screw press. The dewatering operation was done for 4 days to give room for spontaneous fermentation of the mash. Subsequently, the fermented mash was pulverized manually and sieved with a $1.18 \mathrm{~mm}$ sieve (United States Pharmacopoeia Standard Sieves). The overtail was discarded and the resulting mash was used for sakada production immediately.

\section{Production of African yam bean flour}

The method of Ndidi et al. (2014) was used for the production of African yam bean flour (AYF). African yam beans were dry-cleaned, washed with water, and de-hulled manually. The de-hulled beans were boiled in water $(1: 6, \% \mathrm{w} / \mathrm{v})$ for $45 \mathrm{~min}$, cooled, and dried at $60{ }^{\circ} \mathrm{C}$ for $18 \mathrm{~h}$. The dried beans were milled and sieved to obtain a flour with average particle size of $0.25 \mathrm{~mm}$.

\section{Preparation of fermented cassava mash and African yam bean flour blends for sakada production}

Fermented cassava mash was blended with AYF at levels (\%, w/w) 100:0 (control), 90:10, 80:20, 70:30, and 60:40. Each blend was properly mixed to form a dough-like mass and sized with a $9.0 \mathrm{~cm}$ plastic doughnut cutter (Generic, China). The dough-like mass was roasted in a locally fabricated gas oven at $110^{\circ} \mathrm{C}$ for $20 \mathrm{~min}$. Sakada samples were rapidly cooled to room temperature $\left(28 \pm 2{ }^{\circ} \mathrm{C}\right)$ and subjected to analyses immediately.

\section{Analyses of sakada samples}

AOAC (2005) methods were used for proximate, mineral $(\mathrm{P}, \mathrm{Na}, \mathrm{K}, \mathrm{Mg}$, and $\mathrm{Ca}$ ), and cyanide contents while AOAC (2000) methods were used for phytate and oxalate contents.

Quantification of amino acids in sakada was performed with an amino acid analyzer (Technicon TSM 1, UK) (Margier et al., 2018). Sakada sample was ground in a mortar and pestle and subjected to different hydrolyses. These included acid hydrolysis and oxidation using $6 \mathrm{~N} \mathrm{HCl}$ for $24-48 \mathrm{~h}$ at $110{ }^{\circ} \mathrm{C}$ to liberate branched and sulphurcontaining amino acids. These were followed with basic hydrolysis using $4 \mathrm{~N} \mathrm{Ba}(\mathrm{OH})_{2}$ for $20 \mathrm{~h}$ at 100 ${ }^{\circ} \mathrm{C}$. Norleucine was used as a standard.

A 9-point Hedonic scale was used for the sensory evaluation of sakada (Akinwale et al., 2017). For the analysis, fifty panellists were recruited to rate the sakada samples for taste, aroma, colour, texture, and overall acceptability. Sakada samples were served to the panellists at $70^{\circ} \mathrm{C}$ in individual booths under white fluorescent light. Potable water was provided for palate cleansing in between samples. 


\section{RESULTS AND DISCUSSION}

\section{Proximate composition of sakada}

The proximate composition of sakada produced using FCM and AYF is presented in Table 1. The inclusion of AYF in FCM caused a reduction ( $\mathrm{p}<$ 0.05 ) in the moisture content of sakada. Besides, moisture content decreased with an increasing level of AYF. This could be due to the low moisture content of AYF and the effectiveness of the drying operation. This implied an improvement in the stability of sakada containing AYF because low moisture content $(<8.50 \%)$ of products would reduce microbial spoilage (Iwe et al., 2016). A similar result was reported for wheat-groundnut protein concentrate blends (Ocheme et al., 2018). The sakada produced using 100\% FCM (SAYF0) and the one produced using $60 \% \mathrm{FCM}$ and $40 \%$ AYF (SAYF4) having the lowest and the highest values, respectively. The result implied that the protein content of sakada increased following the addition of AYF. Maziya-Dixon et al. (2017) also reported that the protein content of a cassava-based snack increased after enrichment with soybean and cowpea flours. According to Olawuni et al. (2014), African yam bean has a high protein content $(22.50 \%)$, therefore, its inclusion in carbohydratebased foods will help combat nutrition insecurity that arises from protein-energy malnutrition. The fat content of sakada increased, from $0.99 \mathrm{~g} / 100 \mathrm{~g}$ (in SAYF0) to a maximum value of $2.03 \mathrm{~g} / 100 \mathrm{~g}$, consequent to the incorporation of AYF. The increase could be due to the high fat content of AYF. Uzo-Peters et al. (2008) also reported fat increase in kokoro (a maize-based snack) following its enrichment with groundnut cake. This is advantageous because, the shortening effect of fat will improve the sensorial properties, especially texture and appearance (Ayele et al., 2017).

Ash content followed a similar trend. This could be attributed to the high ash content of African yam bean (Olawuni et al., 2014). This agreed with Igbabul et al. (2019), who reported that mineral content of wheat-based bread increased consequent to the addition of hamburger bean. Crude fibre did not differ $(\mathrm{p}>0.05)$ among SAYF0, sakada produced using 90\% FCM and 10\% AYF (SAYF1), and sakada produced using $80 \%$ FCM and $20 \%$ AYF (SAYF2). However, crude fibre decreased significantly $(\mathrm{p}<0.05)$ when the level of AYF exceeded $30 \%$. Significantly $(p<0.05)$ higher crude fibre obtained for the sakada samples that contained $\leq 20 \%$ AYF indicated better glycemic and prebiotic properties (Igbabul et al., 2019). The carbohydrate content of sakada decreased as the level of AYF increased. The increase in protein and fat contents of sakada, following AYF inclusion, might be responsible for the decrease. Reduction in carbohydrate content could imply better digestibility of the product (Iwe et al., 2016).

\section{Mineral composition of sakada}

The mineral profile of sakada produced from blends of FCM and AYF is presented in Table 2. The blending of FCM and AYF increased $(\mathrm{p}<0.05) \mathrm{P}$, $\mathrm{Na}, \mathrm{K}, \mathrm{Mg}$, and $\mathrm{Ca}$ contents of sakada. Also, the increment was dependent on the level AYF in the blends. This finding indicated the low mineral content of sakada, hence, the need for macroelement fortification (Chadare et al., 2019). High mineral profile of African yam bean could be responsible for the increase in the mineral profile of sakada. Ndidi et al. (2014) had reported a high concentration of minerals, such as $\mathrm{Na}, \mathrm{Ca}, \mathrm{K}, \mathrm{Fe}$, $\mathrm{Cu}, \mathrm{Zn}$, and $\mathrm{Mg}$, in African yam bean. Ayele et al. (2017) also reported that $\mathrm{Ca}$ and $\mathrm{Fe}$ of wheat-based bread increased following the addition of soybean flour. Mineral elements function in various metabolic responses in the body, therefore, the high mineral profile of sakada enriched with AYF indicated an improved nutrient density of the product (Ayele et al., 2017).

Table 1. Proximate composition of sakada produced from blends of fermented cassava mash and African yam bean

\begin{tabular}{|l|l|l|l|l|l|l|}
\hline Sakada & $\begin{array}{l}\text { Moisture } \\
\text { content } \\
(\mathrm{g} / 100 \mathrm{~g})\end{array}$ & $\begin{array}{l}\text { Protein } \\
(\mathrm{g} / 100 \mathrm{~g})\end{array}$ & Fat $(\mathrm{g} / 100 \mathrm{~g})$ & $\begin{array}{l}\text { Crude fibre } \\
(\mathrm{g} / 100 \mathrm{~g})\end{array}$ & Ash $(\mathrm{g} / 100 \mathrm{~g})$ & $\begin{array}{l}\text { Carbohydrate } \\
(\mathrm{g} / 100 \mathrm{~g})\end{array}$ \\
\hline $\begin{array}{l}\text { SAYF0 } \\
\text { (control) }\end{array}$ & $11.43^{\mathrm{a}} \pm 0.02$ & $1.97^{\mathrm{e}} \pm 0.02$ & $0.99^{\mathrm{e}} \pm 0.02$ & $3.67^{\mathrm{a}} \pm 0.01$ & $1.32^{\mathrm{e}} \pm 0.02$ & $80.61^{\mathrm{a}} \pm 0.03$ \\
\hline SAYF1 & $8.64^{\mathrm{b}} \pm 0.01$ & $5.06^{\mathrm{d}} \pm 0.06$ & $1.23^{\mathrm{d}} \pm 0.02$ & $3.65^{\mathrm{a}} \pm 0.01$ & $2.37^{\mathrm{d}} \pm 0.01$ & $79.15^{\mathrm{b}} \pm 0.06$ \\
\hline SAYF2 & $8.25^{\mathrm{c}} \pm 0.01$ & $7.98^{\mathrm{c}} \pm 0.01$ & $1.58^{\mathrm{c}} \pm 0.02$ & $3.63^{\mathrm{a}} \pm 0.02$ & $2.43^{\mathrm{c}} \pm 0.01$ & $76.31^{\mathrm{c}} \pm 0.01$ \\
\hline SAYF3 & $8.14^{\mathrm{d}} \pm 0.01$ & $10.34^{\mathrm{b}} \pm 0.01$ & $1.84^{\mathrm{b}} \pm 0.02$ & $2.98^{\mathrm{b}} \pm 0.02$ & $2.78^{\mathrm{b}} \pm 0.01$ & $73.73^{\mathrm{d}} \pm 0.03$ \\
\hline SAYF4 & $8.14^{\mathrm{d}} \pm 0.02$ & $12.08^{\mathrm{a}} \pm 0.01$ & $2.03^{\mathrm{a}} \pm 0.01$ & $2.82^{\mathrm{c}} \pm 0.01$ & $2.99^{\mathrm{a}} \pm 0.01$ & $71.95^{\mathrm{e}} \pm 0.01$ \\
\hline
\end{tabular}

The data presented are means and standard deviations of triplicate scores. Different superscripts on mean values within a column indicated that the data were significant $(\mathrm{p}<0.05)$ different. SAYF0-Sakada produced using 100\% cassava mash, SAYF1- Sakada produced using 90\% cassava mash and 10\% African yam bean, SAYF2- Sakada produced using $80 \%$ cassava mash and 20\% African yam bean, SAYF3- Sakada produced using $70 \%$ cassava mash and 30\% African yam bean, SAYF4- Sakada produced using 60\% cassava mash and 40\% African yam bean. 
Cyanide, phytate, and oxalate contents of sakada The cyanide, phytate, and oxalate contents of sakada produced using blends of FCM and AYF is presented in Table 3. Sakada samples produced from blends of FCM and AYF had lower cyanide content compared to the SAYF0. The lowest value $(0.014 \%)$ was obtained for SAYF4. The low cyanide content of African yam bean (Ndidi et al., 2014) could be responsible for this. One of the impediments of cassava utilization is the high concentration of cyanogenic glycosides, which breaks down to give toxic cyanide when linamarase enzymes are elaborated (Laswai et al., 2017). Therefore, cassava processing is often targeted to reduce its cyanide content. This study has shown that the incorporation of low-cyanide vegetable proteins, such as African yam bean, could prove effective for cyanide reduction in cassava-based products. The phytate and oxalate contents increased $(\mathrm{p}<0.05)$ as AYF level increased. This increase could be due to the liberation of phytates and oxalates during the roasting operation. Ayele et al. (2017) had attributed high anti-nutrients of heatprocessed products to the liberation of Maillard products following the interaction between amino acids and sugars. The results obtained showed that the incorporation of AYF $(\leq 20 \%)$ did not increase the phytate and oxalate contents of sakada above the permissible level. This agreed with the findings of Awolu and Oseyemi (2016) who reported that the phytate level of wheat-based composite flour that had up to $18.83 \%$ of Bambara groundnut flour was within a safe limit.

Anti-nutrients are known to bind with essential minerals, thus making them unavailable to the body (Awolu and Oseyemi, 2016), therefore, the low phytate and oxalate contents of SAYF1 and SAYF2 implied that they will not interfere with mineral bioabsorption in the body.

\section{Amino acid profile of sakada}

The amino acid profile of sakada as influenced by AYF inclusion is presented in Figure 1. The incorporation of AYF into sakada increased ( $\mathrm{p}<$ 0.05 ) all the amino acids studied. Amino acids are the building blocks of protein molecules (Margier et al., 2018), therefore, the increase in the amino acid composition of sakada produced using FCM and AYF could be connected to their high protein content (Olawuni et al., 2014). This aligned with an increase in the amino acid content of wheat flour following the incorporation of soy flour (Khan et al., 2009). The high amino acid profile of sakada enriched with AYF could imply a high hydrolytic potential of AYF proteins. This will result in a high rate of digestibility, bioavailability, and absorption of AYF proteins in the body (Khan et al., 2009). This aligned with the findings of Esan and Fasasi (2013) who reported a high rate of in vitro hydrolysis of African yam bean proteins.

Table 2. Mineral profile of sakada produced from blends of fermented cassava mash and African yam bean

\begin{tabular}{|l|l|l|l|l|l|}
\hline Sakada & $\begin{array}{l}\mathrm{P} \\
(\mathrm{mg} / 100 \mathrm{~g})\end{array}$ & $\begin{array}{l}\mathrm{Na} \\
(\mathrm{mg} / 100 \mathrm{~g})\end{array}$ & $\begin{array}{l}\mathrm{K} \\
(\mathrm{mg} / 100 \mathrm{~g})\end{array}$ & $\begin{array}{l}\mathrm{Mg} \\
(\mathrm{mg} / 100 \mathrm{~g})\end{array}$ & $\begin{array}{l}\mathrm{Ca} \\
(\mathrm{mg} / 100 \mathrm{~g})\end{array}$ \\
\hline SAYF0 (control) & $16.02^{\mathrm{e}} \pm 0.01$ & $51.22^{\mathrm{e}} \pm 0.03$ & $51.29^{\mathrm{e}} \pm 0.01$ & $8.58^{\mathrm{e}} \pm 0.24$ & $8.74^{\mathrm{e}} \pm 0.01$ \\
\hline SAYF1 & $32.24^{\mathrm{d}} \pm 0.02$ & $57.33^{\mathrm{d}} \pm 0.12$ & $212.44^{\mathrm{d}} \pm 0.01$ & $126.16^{\mathrm{d}} \pm 0.02$ & $10.87^{\mathrm{d}} \pm 0.01$ \\
\hline SAYF2 & $40.13^{\mathrm{c}} \pm 0.03$ & $62.28^{\mathrm{c}} \pm 0.42$ & $267.51^{\mathrm{c}} \pm 0.01$ & $132.82^{\mathrm{c}} \pm 0.02$ & $15.81^{\mathrm{c}} \pm 0.06$ \\
\hline SAYF3 & $45.62^{\mathrm{b}} \pm 0.01$ & $68.16^{\mathrm{b}} \pm 0.01$ & $299.33^{\mathrm{b}} \pm 0.01$ & $148.62^{\mathrm{b}} \pm 0.01$ & $25.42^{\mathrm{b}} \pm 0.01$ \\
\hline SAYF4 & $51.62^{\mathrm{a}} \pm 0.02$ & $72.73^{\mathrm{a}} \pm 0.03$ & $352.74^{\mathrm{a}} \pm 0.01$ & $154.04^{\mathrm{a}} \pm 0.01$ & $31.16^{\mathrm{a}} \pm 0.01$ \\
\hline
\end{tabular}

The data presented are means and standard deviations of triplicate scores. Different superscripts on mean values within a column indicated that the data were significant $(\mathrm{p}<0.05)$ different. SAYF0- Sakada produced using $100 \%$ cassava mash, SAYF1- Sakada produced using 90\% cassava mash and 10\% African yam bean, SAYF2- Sakada produced using $80 \%$ cassava mash and 20\% African yam bean, SAYF3- Sakada produced using 70\% cassava mash and 30\% African yam bean, SAYF4- Sakada produced using 60\% cassava mash and 40\% African yam bean.

Table 3. Cyanide, phytate, and oxalate of sakada produced from blends of fermented cassava mash and African yam bean

\begin{tabular}{|l|l|l|l|}
\hline Sakada & Cyanide $(\%)$ & Phytate $(\%)$ & Oxalate $(\%)$ \\
\hline SAYF0 (control) & $0.029^{\mathrm{a}} \pm 0.001$ & $0.563^{\mathrm{e}} \pm 0.002$ & $0.350^{\mathrm{e}} \pm 0.010$ \\
\hline SAYF1 & $0.025^{\mathrm{b}} \pm 0.001$ & $0.597^{\mathrm{d}} \pm 0.00$ & $0.720^{\mathrm{d}} \pm 0.020$ \\
\hline SAYF2 & $0.021^{\mathrm{c}} \pm 0.001$ & $0.766^{\mathrm{c}} \pm 0.001$ & $1.450^{\mathrm{c}} \pm 0.011$ \\
\hline SAYF3 & $0.018^{\mathrm{d}} \pm 0.001$ & $0.782^{\mathrm{b}} \pm 0.001$ & $2.087^{\mathrm{b}} \pm 0.015$ \\
\hline SAYF4 & $0.014^{\mathrm{e}} \pm 0.001$ & $0.795^{\mathrm{a}} \pm 0.002$ & $2.650^{\mathrm{a}} \pm 0.010$ \\
\hline
\end{tabular}

The data presented are means and standard deviations of triplicate scores. Different superscripts on mean values within a column indicated that the data were significant $(\mathrm{p}<0.05)$ different. SAYF0-Sakada produced using 100\% cassava mash, SAYF1- Sakada produced using 90\% cassava mash and 10\% African yam bean, SAYF2- Sakada produced using $80 \%$ cassava mash and 20\% African yam bean, SAYF3- Sakada produced using $70 \%$ cassava mash and 30\% African yam bean, SAYF4- Sakada produced using $60 \%$ cassava mash and $40 \%$ African yam bean. 
High concentration $(>4.0 \mathrm{~g} / 100 \mathrm{~g}$ protein) of essential amino acid, arginine, was recorded for SAYF1 and SAYF2. Other important essential amino acids, i.e. leucine, isoleucine, and phenylalanine, were obtained in high concentration $(>4.0 \mathrm{~g} / 100 \mathrm{~g}$ protein) in SAYF2. Cysteine and methionine, which are limiting in African yam bean, were detected in an appreciable quantity in sakada produced using the blends FCM and AYF. This could be due to the complementation effect of amino acids in FCM and AYF, which probably led to more balanced amino acids in sakada. This is of high nutritional benefit because AYF-enriched sakada will be a carrier of essential amino acids that are not readily synthesized in the body (Margier et al., 2018).

\section{Sensory properties of sakada}

The sensory properties of sakada, in terms of the degree of liking, is presented in Table 4. A higher consumer acceptance in terms of taste and aroma was recorded for SAYF1 and SAYF2 compared to SAYF0. However, panellists showed a low preference for sakada produced using 70\% FCM and $30 \%$ AYF (SAYF3) and SAYF4. This implied that the incorporation of $\leq 20 \%$ AYF into FCM improved the taste and aroma of sakada. This could be due to the elaboration of flavour compounds from the interaction between the sugars and proteins in FCM and AYF during the roasting operation. Laswai et al. (2017) also reported that the incorporation of $20 \%$ soybean improved the sensory properties of cassava-based pancakes. The low aroma and taste preference recorded for SAYF3 and SAYF4 could be due to the high level of AYF in sakada, which probably caused a beany flavour. According to Ocheme et al. (2018), high legume composition in foods causes a strong beany flavour, which can result in low consumer preference for the products. SAYF0 and SAYF1 did not differ ( $\mathrm{p}>$ 0.05 ) in terms of colour, however, the incorporation of $>10 \%$ AYF caused a reduction in the preference for colour. This could be due to the increased rate of elaboration of colour compounds owing to the browning reaction resulting from the high level of protein in AYF and sugars in FCM (Ayele et al., 2017). The incorporation of AYF in sakada caused a reduction in its degree of liking in terms of texture. This could be due to the reduction of starch in sakada, consequent to AYF enrichment, and this probably caused the softening of the product. Laswai et al. (2017) also reported the softening of cassava-based pancakes following the incorporation of soy flour.

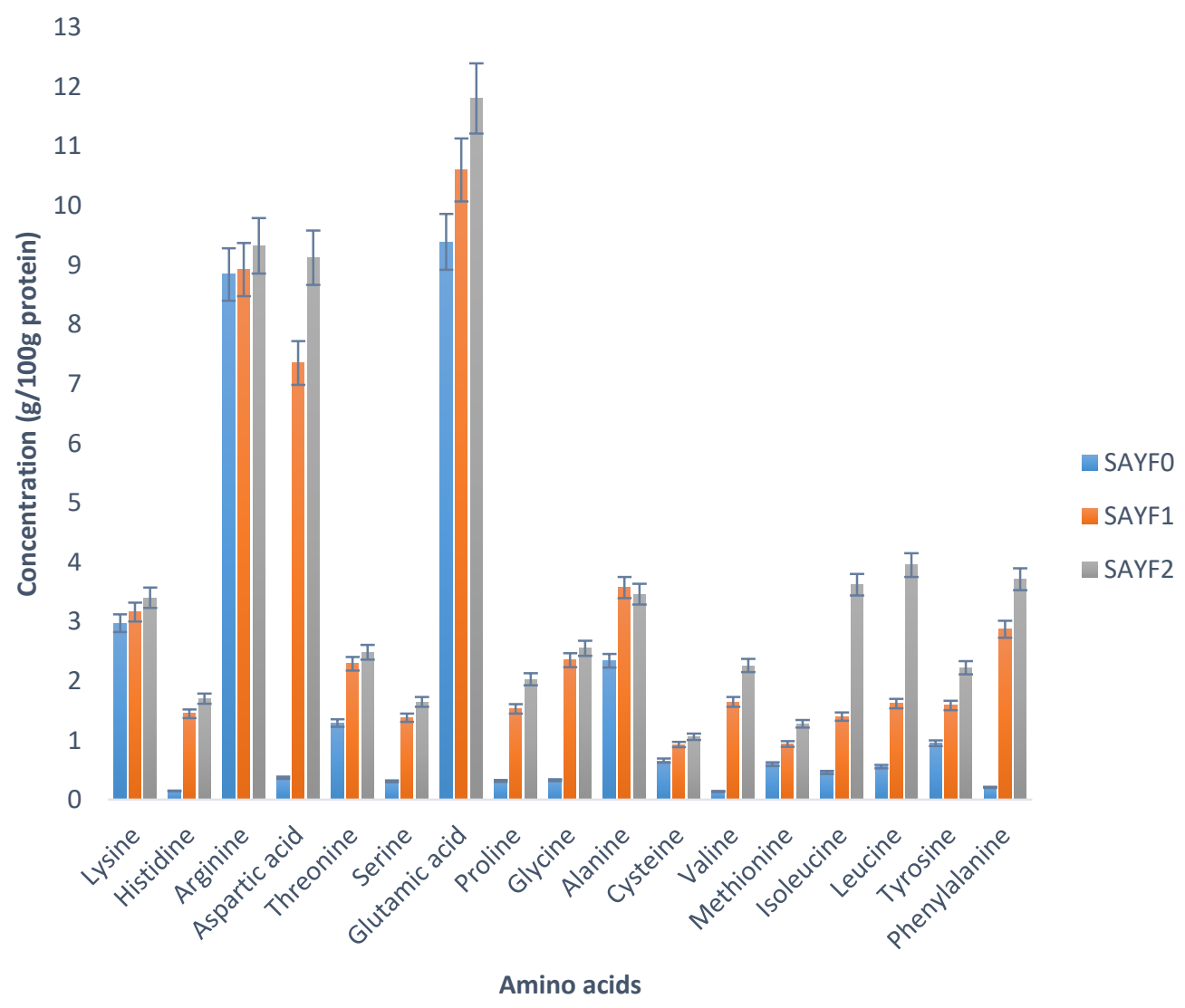

Figure 1. Amino acid profile of sakada enriched with African yam bean. SAYF0- Sakada produced using $100 \%$ cassava mash, SAYF1- Sakada produced using 90\% cassava mash and 10\% African yam bean, SAYF2- Sakada produced using $80 \%$ cassava mash and $20 \%$ African yam bean. 
Results showed a higher level of SAYF1 and SAYF2 acceptance in terms of texture compared to SAYF3 and SAYF4. This could imply a higher softening of sakada that contained a high level $(>20 \%)$ of AYF. The highest overall acceptability (8.26) was recorded for SAYF0 probably due to the familiarity of the panellists to sakada produced solely from cassava mash. SAYF1 and SAYF2 did not differ $(p>0.05)$ in terms of overall acceptability. Significantly $(\mathrm{p}<0.05)$ higher scores were recorded for the samples compared to SAYF3 and SAYF4. This implied that consumers would tolerate up to $20 \%$ of the AYF level in sakada.

Table 4. Sensory properties of sakada produced from blends of fermented cassava mash and African yam bean

\begin{tabular}{|l|l|l|l|l|l|}
\hline Sakada & Taste & Aroma & Colour & Texture & $\begin{array}{l}\text { Overall } \\
\text { acceptability }\end{array}$ \\
\hline SAYF0 (control) & $7.00^{\mathrm{b}} \pm 0.20$ & $7.43^{\mathrm{b}} \pm 0.20$ & $6.96^{\mathrm{a}} \pm 0.30$ & $8.40^{\mathrm{a}} \pm 0.10$ & $8.26^{\mathrm{a}} \pm 0.20$ \\
\hline SAYF1 & $7.86^{\mathrm{a}} \pm 0.20$ & $7.13^{\mathrm{c}} \pm 0.30$ & $6.93^{\mathrm{a}} \pm 0.20$ & $6.36^{\mathrm{b}} \pm 0.20$ & $7.83^{\mathrm{b}} \pm 0.20$ \\
\hline SAYF2 & $7.90^{\mathrm{a}} \pm 0.30$ & $7.80^{\mathrm{a}} \pm 0.30$ & $6.63^{\mathrm{ab}} \pm 0.10$ & $6.36^{\mathrm{b}} \pm 0.10$ & $7.78^{\mathrm{b}} \pm 0.10$ \\
\hline SAYF3 & $4.53^{\mathrm{c}} \pm 0.40$ & $4.70^{\mathrm{d}} \pm 0.20$ & $6.50^{\mathrm{ab}} \pm 0.10$ & $4.40^{\mathrm{c}} \pm 0.10$ & $5.23^{\mathrm{c}} \pm 0.10$ \\
\hline SAYF4 & $3.46^{\mathrm{d}} \pm 0.20$ & $4.46^{\mathrm{e}} \pm 0.20$ & $6.40^{\mathrm{b}} \pm 0.20$ & $3.40^{\mathrm{d}} \pm 0.20$ & $3.46^{\mathrm{d}} \pm 0.30$ \\
\hline
\end{tabular}

The data presented are means and standard deviations of fifty scores. Different superscripts on mean values within a column indicated that the data were significant $(\mathrm{p}<0.05)$ different. SAYF0-Sakada produced using $100 \%$ cassava mash, SAYF1- Sakada produced using $90 \%$ cassava mash and $10 \%$ African yam bean, SAYF2- Sakada produced using $80 \%$ cassava mash and 20\% African yam bean, SAYF3- Sakada produced using 70\% cassava mash and 30\% African yam bean, SAYF4- Sakada produced using $60 \%$ cassava mash and $40 \%$ African yam bean.

\section{CONCLUSIONS}

The incorporation of African yam bean improved the nutritional and sensory qualities of sakada. There was a significant $(\mathrm{p}<0.05)$ increase in the protein, fat, $\mathrm{P}, \mathrm{Na}, \mathrm{Ca}, \mathrm{Mg}$, and $\mathrm{Ca}$ contents of sakada as the level of AYF increased while ash and carbohydrate decreased. The toxicity (cyanide) level of sakada reduced following the incorporation
AYF. The incorporation of AYF $(\leq 20 \%)$ did not increase the phytate and oxalate content of sakada beyond safety limit. This level of AYF inclusion also resulted in a high concentration of important amino acids such as arginine, leucine, isoleucine, and phenylalanine. The sensory evaluation result showed that the sakada samples that had up to $20 \%$ AYF were acceptable by the panelists in terms of taste, aroma, texture, and overall acceptability.

\section{REFERENCES}

1. Ajani, A.O., Alade, O.A., Olagbaju, A.R., Fasoyiro, S.B., Arowora, K.A. \& Oyelakin, M.O. (2016). Chemical and sensory qualities of stored gari fortified with soybean and groundnut flour. Applied Tropical Agriculture, 21(2), 79-83.

2. Akinwale, T.E., Shittu, T.A,, Adebowale, A.A., Adewuyi, S. \& Abass A.B. (2017). Effect of soy protein isolate on the functional, pasting, and sensory acceptability of cassava starch- based custard. Food Science and Nutrition, 5, 1163-1169.

3. AOAC (2000). Official Methods of Analysis, Washington, DC., Association of the Official Analytical Chemists.

4. AOAC (2005). Official Methods of Analysis, Gathersburg, MD U.S.A, Association of Official Analytical Chemists International.

5. Aristizábal, J., García, J.A. \& Ospina, B. (2017). Refined cassava flour in bread making: a review. Ingeniería e Investigación, 37(1), 25-33. http://dx.doi.org/10.15446/ing.investig.v37n1.57306

6. Awolu, O.O. \& Oseyemi, G.F. (2016). Physicochemical and rheological properties of optimised cocoyam-based composite flour comprising cassava starch. Acta Universitatis Cibiniensis Series E: Food Technology, 20(2), 65-84. 10.1515/aucft-2016-0016.

7. Ayele, H.A., Bultosa, G., Abera, T. \& Astatkie, T. (2017). Nutritional and sensory quality of wheat bread supplemented with cassava and soybean flours. Cogent Food and Agriculture, 3, 1331892. https://doi.org/10.1080/23311932.2017.1331892. 
8. Banigo, E.B. \& Kiin-Kabari, D.B. (2016). Effect of African yam bean (AYB) (Sphenostylis stenocarpa) on the quality characteristic of extended meat ball. Journal of Food and Nutrition Research, 4(2), 121125. 10.12691/jfnr-4-2-9.

9. Chadare, F.J., Idohou, R., Nago, E., Affonfere, M., Agossadou, J., Fassinou, T.K., Kénou, C., Honfo, S., Azokpota, P., Linnemann, A.R. \& Hounhouigan, D.J. (2019). Conventional and food-to-food fortification: An appraisal of past practices and lessons learned. Food Science and Nutrition, 7, 27812795

10. Eduardo, M., Svanberg, U., Oliveira, J. \& Ahrné, L. (2013). Effect of cassava flour characteristics on properties of cassava-wheat-maize composite bread types. International Journal of Food Science, 2013, 305407. http://dx.doi.org/10.1155/2013/305407

11. Esan, Y.O. \& Fasasi, O.S. (2013). Amino acid composition and antioxidant properties of African yam bean (Spenostylis stenocarpa) protein hydrolysates. African Journal of Food Science and Technology, 4(5), 100-105.

12. Food and Agriculture Organization (2020). Cassava. Retrieved on 23 June, 2020, from http://www.fao.org/3/x4007e/X4007E04.htm\#: :text=Cassava\%20yields\%20vary\%20with\%20cultivars ,cassava\%20yields\%20are\%20much\%20lower.

13. Idowu, A. (2015). Chemical composition and sensory and pasting properties of blends of maize-African yam bean seed. Journal of Nutritional Health and Food Science, 3(3), 1-6. http://dx.doi.org/10.15226/jnhfs.2015.00146

14. Igbabul, B.D., Onoja, E.C. \& Ukeyima, M.T. (2019). Quality evaluation of composite bread produced from wheat, water yam and brown hamburger bean flours. African Journal of Food Science and Technology, 10(2), 42-48. http:/dx.doi.org/10.14303/ajfst.2019.008

15. International Institute for Tropical Agriculture (2020). Cassava. Retrieved on 23 June, 2020, fromhttps://www.iita.org/cropsnew/cassava/\#: :text=More\%20than\%20291\%20million\%20tons,increas e\%20in\%20the\%20last\%20decade.

16. Iwe, M.O., Onyeukwu, U. \& Agiriga. A.N. (2016). Proximate, functional and pasting properties of FARO 44 rice, African yam bean and brown cowpea seeds composite flour. Cogent Food and Agriculture, 2, 1142409.

17. Jisha, S., Sheriff, J.T. \& Padmaja, G. (2010). Nutritional, functional and physical properties of extrudates from blends of cassava flour with cereal and legume flours. International Journal of Food Properties, 13(5), 1002-1011. https://doi.org/10.1080/10942910902934090.

18. Khan, M.I., Anjum, F.M., Zahoor, T., Sarwar, M. \& Ahab, S. (2009). Nutritional characterization of wheat-soy unleavened flat bread by rat bioassay. Sarhad Journal of Agriculture, 25(1), 73-80.

19. Laswai, H. S., Pacific, R. \& Hussein, J. (2017). Suitability of cassava starch in making baked and fried composite flour products. Tanzania Journal of Agricultural Sciences, 16(1), 9-16.

20. Laya, A., Koubala, B.B., Kouninki, H. \& Nukenine, E.N. (2018). Effect of harvest period on the proximate composition and functional and sensory properties of gari produced from local and improved cassava (Manihot esculenta) varieties. International Journal of Food Science, 2018, 6241035. https://doi.org/10.1155/2018/6241035

21. Maziya-Dixon, B., Alamu, E.O., Popoola, I.O. \& Yomeni, M. (2017). Nutritional and sensory properties: Snack food made from high-quality cassava flour and legume blend. Food Science and Nutrition, 5:805811. 10.1002/fsn3.464.

22. Margier, M., Georgé, S., Hafnaoui, N., Remond, D., Nowicki, M., Du Chaffaut, L., Amiot, M. \& Reboul, E. (2018). Nutritional composition and bioactive content of legumes: characterization of pulses frequently consumed in France and effect of the cooking method. Nutrients, 2018, 10, 1668. 10.3390/nu10111668

23. Ndidi, U.S., Ndidi, C.U., Olagunju, A., Muhammad, A., Billy, F.G. \& Okpe, O. (2014). Proximate, antinutrients and mineral composition of raw and processed (boiled and roasted) Sphenostylis stenocarpa seeds from Southern Kaduna, Northwest Nigeria. ISRN Nutrition, 2014, 280837. http://dx.doi.org/10.1155/2014/280837

24. Obadina, O.A., Oyewole, O.B., \& Williams. O.E. (2013). Improvement in the traditional processing method and nutritional quality of traditional extruded cassava-based snack (modified Ajogun), Food Science and Nutrition, 1(4), 350-356.

25. Ocheme, O.B., Adedeji, O.E., Chinma, C.E., Yakubu, C.M. \& Ajibo UH. (2018). Proximate composition, functional and pasting properties of wheat and groundnut protein concentrate flour blends. Food Science and Nutrition, 6(5), 1173-1178. 
26. Okoye, E.C. \& Ezeugwu, E.H. (2019). Production, quality evaluation and acceptability of bread from wheat, Bambara groundnut and yellow root cassava flours. International Journal of Food and Bioscience, $1(2), 11-17$.

27. Olawuni, I., Osobie, C.C., Peter-Ikechukwu, A., Kabuo, O.N., Bede, N.E. \& Odimegwu, N. (2014). Physicochemical and functional properties of flour from dehulled white African Yam Bean (Sphenostylis sternocarpa) grown in Anambra state, Nigeria. Natural Products, 10(6), 171-177.

28. Uzor-Peters, P.I., Arisa, N.U., Lawrence, C.O., Osondu, N.S. \& Adelaja, A. (2008). Effect of defatted soybean and groundnut flours on proximate and sensory characteristics of kokoro. African Journal of Food science, 2, 98-101.

29. Wordu, G. O. \& Akusu, M. O. (2016). Nutritional and sensory evaluation of enriched gurudi (a cassava starch snack food). International Journal of Research Studies in Biosciences, 4(1), 28-31. http://dx.doi.org/10.20431/2349-0365.0401006. 